$\stackrel{\circ}{\|}$

\title{
NEIGHBOURHOOD CIRCLES: THE STUDY OF URBAN NEIGHBOURHOOD IN CONTEMPORARY POLAND AND ITS BASIC OUTCOMES
}

ABSTRACT. Marek Nowak, Przemysław Pluciński, Andrzej Siatkowski, Neighbourhood Circles: The Study of Urban Neighbourhood in Contemporary Poland and Its Basic Outcomes [Kręgi sąsiedzkie: studium miejskiego sąsiedztwa we współczesnej Polsce, główne ustalenia] edited by M. Nowak, "Człowiek i Społeczeństwo" vol. XLVIII: Kuchnia badań miejskich. Studia na temat praktyki empirycznej badaczy miasta [A backstage of urban research], Poznań 2019, pp. 55-73, Adam Mickiewicz University. ISSN 0239-3271.

The article presents the problems of urban neighbourhood organized regarding its theoretical and empirical nature. It presents both the history and the theoretical discussion of neighbourhood research, especially within the frames of Polish sociology, although not exclusively, as well as empirical results of the latest research conducted in three cities of different size (Warsaw, Poznań, Wronki) in 2019. Partial results of the research presented in the article focus on factors conducive to building neighbourly relations.

Marek Nowak, Uniwersytet im. Adama Mickiewicza w Poznaniu, Wydział Socjologii, ul. Szamarzewskiego 89, 60-568 Poznań, e-mail: marek.nowak@amu.edu.pl

Przemysław Pluciński, Uniwersytet im. Adama Mickiewicza w Poznaniu, Wydział Socjologii, ul. Szamarzewskiego 89, 60-568 Poznań, e-mail: plucin@amu.edu.pl

Andrzej Siatkowski, Centrum Badań Społecznych Fundacji UAM, ul. Szamarzewskiego 89, 60-568 Poznań, e-mail: andrzej.siatkowski@amu.edu.pl

\section{Introduction}

The article deals with the issues of urban neighbourhood in theoretical and empirical terms. It presents both the history and theoretical discussion about neighbourhood research, taking into account the history of Polish sociology, 
as well as empirical results of the research conducted by the authors of the article. The empirical part of the article presents the results of the latest research carried out within the neighbourhood relations in Poznań, Warsaw and Wronki in 2019, particularly those built in the late socialist, modernist period.

The collected quantitative data $(\mathrm{N}=1800)$ were analysed according to factors conducive to building neighbourly relations and those that undermine it. The conclusions of the analysis aim to indicate the fields of potential development of the reflection and its significance for the appreciation of the revitalization potential contained in modernist housing estates.

\section{Preliminary Remarks}

Urban neighbourhood appears to be a significant issue, mainly due to problems and opportunities it brings, especially when neighbourhood relations can be strengthened or possibly rebuilt, e.g. where their strength is a result of the local communities' traditions. The reference to very traditional community ties is not accidental here; it is a recapitulation of the process of migration from rural to urban areas, well-described by sociologists. Especially in Central and Eastern Europe where, on the one hand, urbanization has been inserted in the universal modernization processes since the mid-19th century, whereas on the other hand it still pursued ideological goals after the change of system to real socialism after World War II. The urbanization specificity, particularly in relation to Le Corbusierian modernism, was somewhat delayed in relation to Western Europe. A canonical example of such processes in Poland were social and spatial changes in Łódź (Pobłocki, 2011) or Nowa Huta near Kraków (cf. Pluciński, 2019: 17), but also in smaller city centres, such as: Bełchatów, Głogów, Jastrzębie Zdrój, Konin, Legnica, Łęczna, Lubin, Płock, Polkowice, Puławy, Tarnobrzeg, Tychy that became in fact "new towns" located in the neighbourhood of the “old ones” (Węcłowicz, 2016).

The results of classical studies on these issues indicate at least two moments in time. On the one hand, one could notice disintegration of community ties linking inhabitants with the place. On the other hand, it quickly turned out that the neighbourhood ties did not completely disintegrate but clearly changed their nature, taking on "the substance" of the neighbourhood circles, i.e. relations of different strength and content: those founded on sharing similar space, having similar problems and building a certain 
degree of interdependence. The last observed stage in the evolution of the neighbourhood was a spatial emancipation of the neighbourhood when it turned out that the growing spatial mobility had modified interpersonal relations but had not shattered them completely.

Nowadays, bonds built in a specific place and time (within the same network of relationships) are maintained, whether in the form of direct communication (meetings, spending time together) the indirect one (telephone or e-mail). Also, these ties take on a completely different meaning when, for example, they provide a basis for maintaining participation in a neighbourhood community through social media, whereas at the same time providing tools for relatively easy access to new relationships based on their preferences, interests and networks built in other places. One can get the impression that not only has the neighbourhood lost none of its importance, but also that it has gained new content; the latter does not mean however that it no longer brings challenges, being obvious and conflict-free. We can analyse here not only the co-presence of different generations and the transmission of patterns between generations, but also the tensions caused by age differences and incompatibility of life phases (compare: Misiak, 1993; Paprzyca, 2009; Niezabitowski, 2011; Nóżka and Martini, 2015; Park and Rogers, 2015; Nóżka, Bukowski, Smagacz-Poziemska and Kurnicki, 2018).

If we realise that neighbourhood ties ${ }^{1}$ are an important element of the social structure in micro- and meso- dimensions, strengthening the sense of existential security and finally rendering life in the city attractive, it turns out that the issue here has gained in importance as a premise for developing solutions to social problems. The aim of the text is therefore to present the conditions which strengthen neighbourly relations in the specific context of development, in order to introduce the reader to the more detailed problem of the revitalization potential of late modernist buildings in a postcommunist city.

\section{Desk Research: Looking for Research Gaps}

The starting point for empirical research was extensive desk research. Catalogues of two libraries were analysed: those of Adam Mickiewicz University and the National Library. The CEJSH, CEEOL and BazHum databases were also examined. Indexes of publications in the journals

\footnotetext{
${ }^{1}$ They play, like all bonds, the role of social life stabilizers.
} 
"Studia Socjologiczne”, "Przegląd Socjologiczny”, and "Studia Regionalne i Lokalne” were analysed as well.

Analysis of the literature has shown that the concept of neighbourhood was frequently used in research on ethnicity and national relations, including historical studies and international relations (e.g. the category of a "difficult neighbourhood”) (Jasińska-Kania, 2001; Dębicki and Doliński 2013). The concept also appears relatively often in the urban context, where the emphasis is placed on infrastructure issues (cf. Sokołowicz, 2017). Applications of the notion of neighbourhood closely related to urban sociology and research on "neighbourhood relations" are much less frequent than those indicated above (from the perspective of the whole researched corpus).

One needs to highlight here the continuity of theorizing and the continuity of research on the neighbourhood in Poland where two periods stand out: the 1920s and 1930s - strongly inspired by the premises of the Chicago School - and the period from the 1960s to the present time, which is probably the effect of "modernization through industrialization and urbanization".

\section{Research on the Neighbourhood in Polish Urban Sociology}

Florian Znaniecki, one of the handful of founders of Polish sociology, put forward the thesis that "a feature of the neighbourhood group (like some other groups) is the strict control of group opinion over the private life of the neighbours” (Znaniecki and Ziółkowski, 1928/1984: 123).

Since the 1960s, the category of neighbourhood and research on neighbourhood has been systematically included in the empirical sociology of the city, especially the research on housing life (cf. Ziółkowski, 1964; Turowski, 1973; Sosnowski and Walkowiak, 1983; Szwaja, 1970), mainly in the new housing estates of blocks of flats, which are supposed to implement the principle of "a decent minimum for the maximum of population". (cf. Ziółkowski, 1965: 53). What was also important at the time was what Smagacz-Poziemska referred to years later as the "rural counterpoint" (Smagacz-Poziemska, 2017: 141). This can be seen, for example, in the research on Nowa Huta (an industrial city built from scratch in the vicinity of Kraków). Researchers were interested in the processes of proletarization and "urbanization of consciousness" of new district/city dwellers coming to Nowa Huta mainly from villages near Kraków. Socialization in order to function correctly in a new spatial and neighbourhood environment became an important element of the research (the research was conducted 
at the turn of the 1960s and 1970s). Katarzyna Szwaja (1970) described the changes in neighbourly and social relations among the proletarian families of Nowa Huta. She claimed that the declared significance of neighbourly relations was still very high among the surveyed families. This indicated a tendency to inherit the vision of social relations from villages. At the same time, 3/4 of the surveyed families maintained such relations: Closer contacts between housewives and children were the most frequent. On the other hand, however, the respondents declared a negative attitude towards maintaining "too close and extensive contacts" with neighbours, fearing "too much interference of neighbours in their family life” (Szwaja, 1970: 9-10).

Other researchers of neighbourly relations in the housing estates of blocks of flats, Sosnowski and Walkowiak, used in turn the term "neighbourly relations" in their research conducted in Szczecin between 1977-1979. In their research, they focus on two issues: firstly, on indicating various spatial neighbourhoods (corridors, storeys, staircases, stairways, hallways, blocks of flats) and secondly, on reflecting neighbourhoods in the consciousness of the respondents, where attitudes towards neighbourhood were stretched between consciously abandoning relationships and building strong ties. As a result, the researchers distinguished as many as 7 types of neighbourly contacts:

- isolated people, i.e. the lack of neighbourhoods, including people actively isolating themselves, i.e. those that take direct action to avoid any contacts;

- people who isolate themselves, but at the same time are convinced of mutual friendliness;

- informed neighbourhood (elementary knowledge about the neighbourhood), but not extended beyond usual politeness and good manners;

- informed and polite neighbourhood;

- exchange of views and information, but without closer contact;

- occasional and beneficial relationship without deepened social relations;

- close neighbourhood - maintaining deep social relations (Sosnowski and Walkowiak, 1983: 236).

Sosnowski and Walkowiak's research revealed a specific paradox: on the one hand, the respondents subjectively indicated a low level of "social contact"; on the other hand, the analysis of real neighbourly contacts indicated many positive, adaptive and integrating functions in the surveyed housing estates. The researchers also pointed out the dominant role of the family and extra-neighbourly relations (including the professional ones) as the dominant models of social life. They also put forward a hypothesis 
concerning the formation of the so-called "greater neighbourhood", i.e. the selection of social contacts relatively independent from the nearest place of residence, connected primarily with spatial dispersion of families in urban centres (Sosnowski and Walkowiak, 1983: 244). This element of the authors' reasoning became a premise for research relevant to the conceptualization of the neighbourhood in the concept of neighbourhood circles.

The transformations connected with the transition to the forms of the "shallow” neighbourhood were also confirmed in Piotr Kryczka's research (1981). Simultaneously, the question here is not about diagnosing a simple erosion of ties, but rather about "a new quality in the field of social ties between dwellers" (Kryczka, 1981: 142). In other words, even "shallow neighbourhoods" (ceremonial or polite) "perform important sociable and controlling functions”, while spatial interfaces give a "possibility of mutual observation” (Smagacz-Poziemska, 2017: 148).

Leaving behind the important topic of conceptualization for the benefit of operationalization, it seems appropriate to tackle the issue concerning definitions of neighbourhood. Let us recall just two definitions rooted in the research practice of the 1970s and 1980s: it is "a community with a homogeneous and coherent character, based on personal relationships, endowed with a strong sense of self-awareness and capable of influencing the behaviour of its members” (Sosnowski and Walkowiak, 1983: 223). And another one by Piotr Kryczka, who understood the neighbourhood as "a system of relatively permanent connections and dependencies between people resulting from the proximity of living, and expressed externally in the form of normalized activities that assume certain obligations and rights of both parties” (Kryczka, 1981: 116).

Neighbourhood research returned to academic discourse at the beginning of the new millennium. In her empirical research carried out in Łódź (2001/2), Anna Bujwicka supplemented the heuristic perspective of the 1970s by adding to it a specific tendency to modify social relations. As she wrote: "economic rationality seems to be one of the principles organizing social relations. This rule directs human activity towards seeking one's own benefits and allows one to treat ties in terms of investment” (Bujwicka, 2011: 103). Here, the economization of ties means a variant of pragmatization of neighbourly relations dictated by individual interests.

This raises the question of whether the relations mentioned above are nowadays really so "mercantilist" in character. Could this be considered as an indicator of the transfer of neighbourly relations from the cultural and social space to the area of exchangeable relations, and thus their clear depletion? Within the framework of the aforementioned Łódź project, the frequency 
of occurrence of a specific type of neighbourly relations (i.e. declarations concerning behaviours) was analysed. The most frequent declarations are an exchange of bows and greetings (86\%), compared to 33\% of declarations of services rendered to neighbours, $29 \%$ of declarations of spending free time with neighbours, $17 \%$ of declarations of seeking information about neighbours and $14 \%$ of declarations of participation in joint neighbourhood initiatives.

In-depth analysis of empirical material leads to the distinction between five types of neighbourhoods:

- conventional neighbourhood - referring to certain normalized activities and actions taking the form of exchanging bows and greetings,

- beneficial neighbourhood - the exchange of various kinds of favours,

- social and friendly neighbourhood - spending free time together,

- informed neighbourhood - expressed in the possession and gathering of information about neighbours,

- solidarity neighbourhood - connected with a sense of superiority and unity of interest.

The proposed categories of types of neighbourhood are not fully separable, but they provide a basis for a deeper analysis based on cluster analysis tools, leading to the identification of three aggregated types of neighbourhood:

- pragmatic neighbourhood - "attaching importance to activity and undertaking it in order to pursue interests in the neighbourhood";

- private neighbourhood - "expected and implemented neighbourhood relations, reaching into the sphere of personal life";

- sentimental-ritual neighbourhood - "imagining the neighbourhood and implementing it only through attachment to social convention" (cf. Bujwicka, 2011: 108 and next).

The pragmatic neighbourhood is related to the age of the respondents, their social and professional category and the type of buildings. The private neighbourhood, as the most far-reaching form, is linked to social and professional category, education and age. Sentimental-ritual neighbourhood is related to age and the length of residence in the given area. It is worth noting that preferred neighbourhood relations did not translate into declarative practices, which indicates a certain dissonance and suggests domination of pragmatism in relationshipsbuilding activities. The neighbourhood image based on the example of Łódź research suggests that the phenomenon of neighbourhood relations, despite its pragmatization, remains important to people, and that neighbourhood relations often go beyond the ritual of greetings, although at the same time it is more an expression of awareness of mutual dependence than a dependence on norms 
requiring the creation of relations. As these are not, therefore, community relations in the classical and traditional sense, this most probably allows defending the proposed conceptualization based on the notion of the neighbourhood circle, i.e. volitional, network, purposeful and spatially rooted relations.

The original perspective is proposed by Jacek Kotus in his work, which is a summary of the research carried out in 2005-06. It is clearly focused, however, on the systemic perspective:

The systemic interpretative perspective makes it possible to distinguish and then analyse empirical examples of the neighbourhood in particular layers: territorial and social. In the social layer, internal relations with the territory and external relations (institutional support) are distinguished (Kotus, 2007: 113).

Therefore, according to Kotus, social and spatial studies of the neighbourhood produce separate, albeit interdependent, analytical areas. The author does not use references to network relations; in his conceptualization, he writes about "neighbourhood subsystems", understood as "the area of direct neighbours, people or families living in adjacent flats or single-family houses, inhabitants of one staircase” (Kotus, 2007: 115). The perspective of specific micro-neighbourhood conditions is strongly emphasized here and can be also treated as a tendency of Polish urban sociology (cf. Majer, 2016; Bierwiaczonek, 2018) to explore personal perspectives.

Kotus' paper illustrates the analytical shift of the point of view from the issues of social features and attributes of neighbourly relations typical of the classical sociology of the city to the grasping of spatial turn aimed at noticing spatial correlates in relation to neighbourly communities. The conclusion is drawn here from space to neighbourhood/community, which is an opposite perspective to the analyses quoted so far. Similarly, the author is rather more interested in analysing direct relations than indirect relations, which is in turn crucial for the adopted concept of neighbourhoods.

The research on neighbourly relations is the subject of analysis beyond the framework of dedicated research programmes. An example of a program in which the neighbourhood was one of the aspects subjected to analysis is a study called "Investigating the quality of life of Poznań dwellers". Within the program, systematic research was conducted using the technique of direct interviews with residents of Poznań. Between 2002-2013, seven measurements were carried out. A scale to evaluate the home and neighbourhood environment for the project was developed in 2006 within the analysed area "Living conditions in the city” (Cichocki and Jabkowski, 2018). Cyclical measurements of the quality of life made possible to analyse changes in the assessment 
of neighbourhood relations in the perspective of a few years. The results for the years 2006-2013 show an increase in the satisfaction of Poznań's inhabitants with the way in which neighbours take care of their immediate surroundings, including mutual assistance, and with the conditions at the playgrounds. At the same time, an in-depth analysis of socio-demographic differences indicated a higher level of satisfaction among people over 40 and residents of two districts dominated by high-rise buildings (residential blocks). These conclusions point to a tendency, also noticed in the present study, to appreciate the neighbourhood in the context of processes improving the quality of life in the city.

\section{Conceptual Design: Towards the Conceptualization and Operationalization of the Neighbourhood Circle}

It was crucial to determine the specific bonds that can be observed in neighbouring circles in selected housing estates of three different cities: Poznań, Warsaw and Wronki. The research was exploratory in nature, taking into account the existing body of knowledge. It also set for itself a certain range of explanatory goals. The scope of the problematization and the list of presented hypotheses were related to the character of the neighbourhood relations with the type of housing, the size of the city, but also to the idea of capturing factors conducive to building neighbourhood relations and those that weaken them. The researchers also answered questions about conditions and barriers to deepen neighbourly ties, which makes practical sense when we look at the neighbourhood as a potential. ${ }^{2}$

The conceptual basis for the given study of neighbourhood was the classical concept of a "social circle", a concept with a long tradition, introduced into academic circulation by George Simmel in a publication from the early 1920s. As David R. Unruh argued, "Simmel notes that voluntarism, segmentation of the life-round, and spatial transcendence characterize social circle (Unruh, 1980: 273)”. The essence of the conceptualization contained here can be reduced to the conviction expressed directly by Simmel that "the ideals of collectivism and individualism are approximated to the same extent (Unruh, 1980: 273)”, i.e. individual claims (interests) meet the

${ }^{2}$ The presented study is a summary of the research and analytical activities carried out under a research project in the period of March-July 2019 including, among others, desk research analysis, analysis of the results from the Internet and questionnaire research including analysis of research walks conducted during this period. 
specificity of a collective life based on (direct) social interactions. Such a way of approaching the metaphor contained in the term the social circle (associated with circles on the water or with a circular shape) perfectly corresponds to the content that we attribute to the neighbourhood, that it is a link between directness of social relations and individual motivations (including voluntary ones) that decides about the content of these relations and maintain them. What is interesting here is the issue of "separation" contained in the metaphor of a circle, where the primordial character of juxtaposing one's own and the other's is exceeded, as well as the spatial substrate which, in turn, addresses the physicality of relations. Interestingly, Simmel's term association and the social circle appear next to each other ${ }^{3}$, which suggests that the social circle is something more than a recapitulation of direct family ties or a direct relationship with a place (where the subject is bound to live). It broadens the understanding of the phenomenon to the area of intentionally produced relationships, where instrumental motifs and indirect production of a broader social organization, going far beyond the people we know, are essential. Such an understanding of the social circle will probably be connected with David R. Unruh's concept of social world or more precisely: regional social world, where the term regional "refer[s] to those social worlds which are predominantly (but by no means totally) comprised of actors, organizations, events, and practices situated within a certain geographical region”. The closest to the neighbourhood will be the understanding of the social circle as local social worlds (Unruh, 1980: 287), knowing that the neighbourhood in the contemporary understanding clearly escapes the understanding of locality. This is due to the emergence of new (social) tools of social communication. Moreover, a similar perspective of the social circle derives to a large extent from the research on the mechanisms of creating a culture and cultural life. The definition proposed below draws attention to the mechanisms of constructing urban culture, which force the use of the humanistic factor (Zemło, 2016) to understand specific relationships based on the subjectivity of individuals. As Charles Kadushin says: "Circles have some distinct properties, ones which often prove puzzling to observers and which make circles emergent, low visibility, interstitial networks (Kadushin, 1976: 770)”. This same feature makes the concept of border clearly deconstructed.

${ }^{3}$ Referring to the fragment cited by David R. Unruh, "Thus the creation of circles and associations in any number of people can come together on the basis of their interest in a common purpose, compensates for that isolation of the personality which develops out of breaking away from the narrow confines of earlier circumstance” (Unruh, 1980: 273). 
Referring to the considerations above, the authors of the research project define a social circle in relation to neighbourhood relations as a set of social and cultural characteristics and the form and content of relationships between people which refer only to the fact that they live together in a spatially delimited area.

Following the proposed approach, neighbourhood and neighbourhood circle are notions which - apart from their intuitive and common sense refer to two important categories of classical urban sociology, especially American sociology, namely community and neighbourhood. The first refers more to a specific type of social cohesion (ethnic, class, etc.), while the latter to the connection between individuals and space, that usually also leads to analyses of specific social interactions. To put it simply, Polish sociologists drew their interest in the neighbourhood mainly from the achievements of the Chicago school (cf. Smagacz-Poziemska, 2017: 141), whether through literature studies (Rychliński, 1976) or direct contacts with American sociology (Znaniecki and Ziółkowski, 1928/1984). It is no coincidence that the notion of neighbourhood appeared in Polish sociology when the sociology of the Chicago school flourished, most likely in the 1930s. Significantly, it is very clear that the understanding of social neighbourhood at that time was very strongly connected with its normative and controlling function. This was present in both the aforementioned Rychliński and Znaniecki (Znaniecki and Ziółkowski, 1928/1984), including empirical studies of Poznań’s inhabitants. There, neighbourhood meant primarily a form of social organization, where social control was an important determinant of actions. Therefore, in the accepted neoclassical understanding, we will consider the neighbourhood as a specificity of the spatially determined social circle, which main feature is the creation of norms and implementation of social control mechanisms.

\section{Methodology of the Study}

Within the framework of the presented project, it was decided to create a significant body of quantitative data in the form of a supplement to the qualitative material. Such specificity of the research premises resulted from the recapitulation of the relatively preliminary level of available neighbourhood analyses in relation to the phenomena that can be described in the context of the evolution of the contemporary city, especially when it comes to its modernist and relatively young parts, the so-called "large-plate blocks of flats”. Two types of quantitative research, based on sociological survey 
methodology, were carried out. An online survey was used and questionnairebased interviews were conducted.

The online survey was conducted on the population of Polish citizens (aged 16 and over) via Facebook. ${ }^{4}$ The survey asked about a few selected key issues: problem of the declared relationship between a resident and a building or a housing estate, a general assessment of the neighbourhood and an individual assessment of one's relations with the neighbours, as well as the question of identifying the problems that most strongly affect the life of the neighbourhood.

Questionnaire interviews were conducted on the population of adult inhabitants of three selected Polish cities (Warsaw, Poznań, Wronki). Residents of Warsaw’s Sady Żoliborskie and Saska Kępa housing estates were selected for the study and in Poznań the study included residents of the Batory and Home Army housing estates. Due to the specificity of housing development in Wronki (no housing estates with characteristics similar to those in Warsaw and Poznań), the study was carried out in this locality on the basis of 10 starting points including both low blocks of flats, houses of multiple occupancy and single-family houses. Both the interview sites (specific housing estates) and the city were selected in such a way that different types of neighbourly relations could be compared with each other. At the same time, the comparability of the type of buildings was assumed in order to identify specific categories of social differences, whereas the researchers were less interested in the impact of the scale of common housing, measured e.g. by the number of family households inhabiting a specific building.

The interview questionnaire was developed on the basis of questions from an online questionnaire and supplemented with additional questions. The tool used in the interviews was therefore developed on the basis of an existing Internet tool.

\section{Two Selected Threads of Empirical Analysis ${ }^{5}$}

On a national scale (Internet survey), friendly space in the neighbourhood (e.g. playgrounds, green areas, etc.) is a key factor in building neighbourly relations. Nearly $92 \%$ of respondents indicated this element as significant.

${ }^{4}$ Initially, 3000 surveys were planned. In the course of implementation, it was decided to reduce the assumed sample size to 1500 surveys. Finally, 1860 completed questionnaires were collected, of which 1854 were included in the analysis (project: Relations in the neighbourhood).

5 Source: data from a research project: Relations in the neighbourhood (2019). 
The shape of neighbourly relations is also supported by common interests (83\% of indications), long-term acquaintances (79\%) and age similarity (78\%). About 3/4 of those surveyed noticed the positive role of creating a meeting space in the building (e.g. utility room, communal area, hallway) in shaping neighbourhood relations. According to the respondents, having children (76\%), as well as having a pet (68\%), may also contribute to establishing contacts with neighbours. Among the highlighted elements in the context of building neighbourhood relations, only the influence of staircases and lifts in the building was ambivalently assessed.

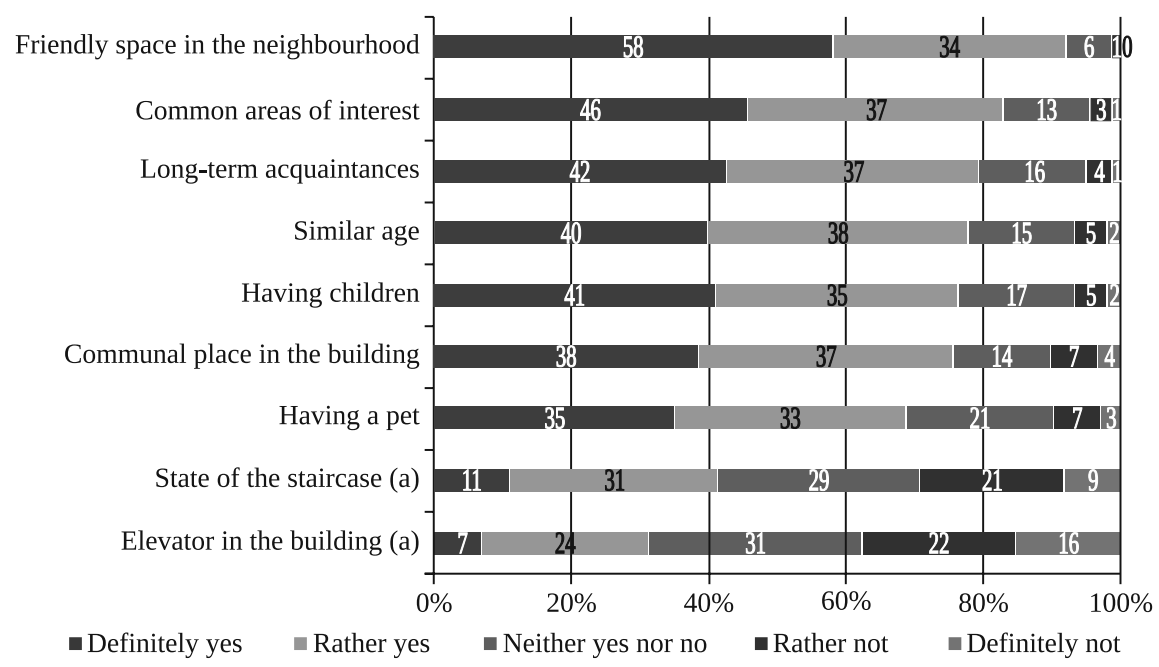

Data in percentage terms

(a) - the elements identified were analysed only in the framework of the PAPI questionnaire survey

Chart 1. Factors conducive to building neighbourly relations

Source: data from a research project: Relations in the neighbourhood.

A detailed analysis of the indicator for the assessment of factors conducive to building neighbourly relations in the form of an arithmetic mean ${ }^{6}$ indicates significant differences in the values of indicators for the inhabitantsof the analysed housing estates in Poznań and Warsaw, as well as in the background of the total results.

${ }^{6}$ In order to determine the value of indicators in the form of an average, five-point scales (from 1 to 5) were transformed into a 100-point scale as follows: definitely yes - 100 points, rather yes -75 points, neither yes or no -50 points, rather not -25 points, definitely not -0 points. 


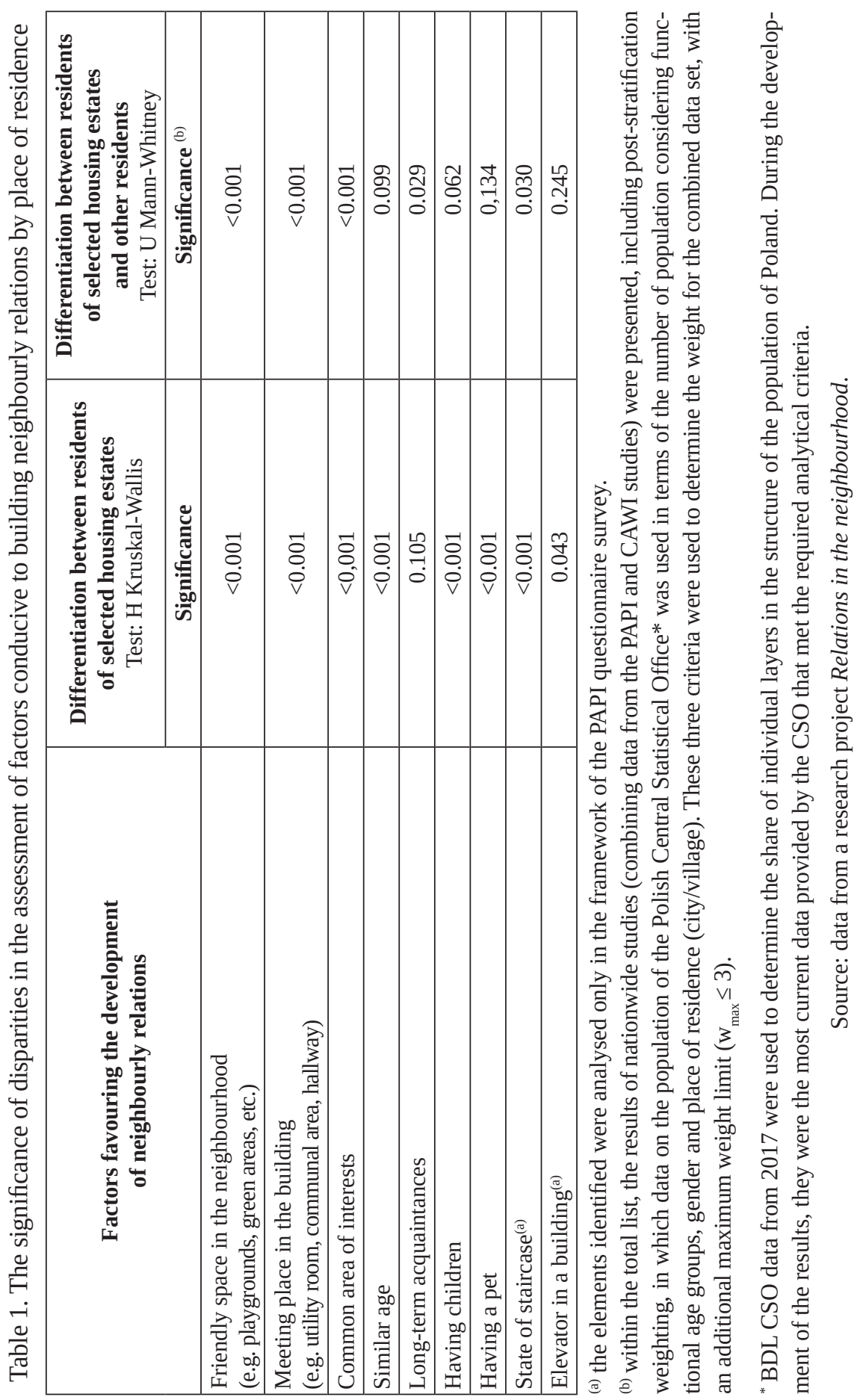


Neighbourhood Circles: The Study of Urban Neighbourhood in Contemporary Poland...

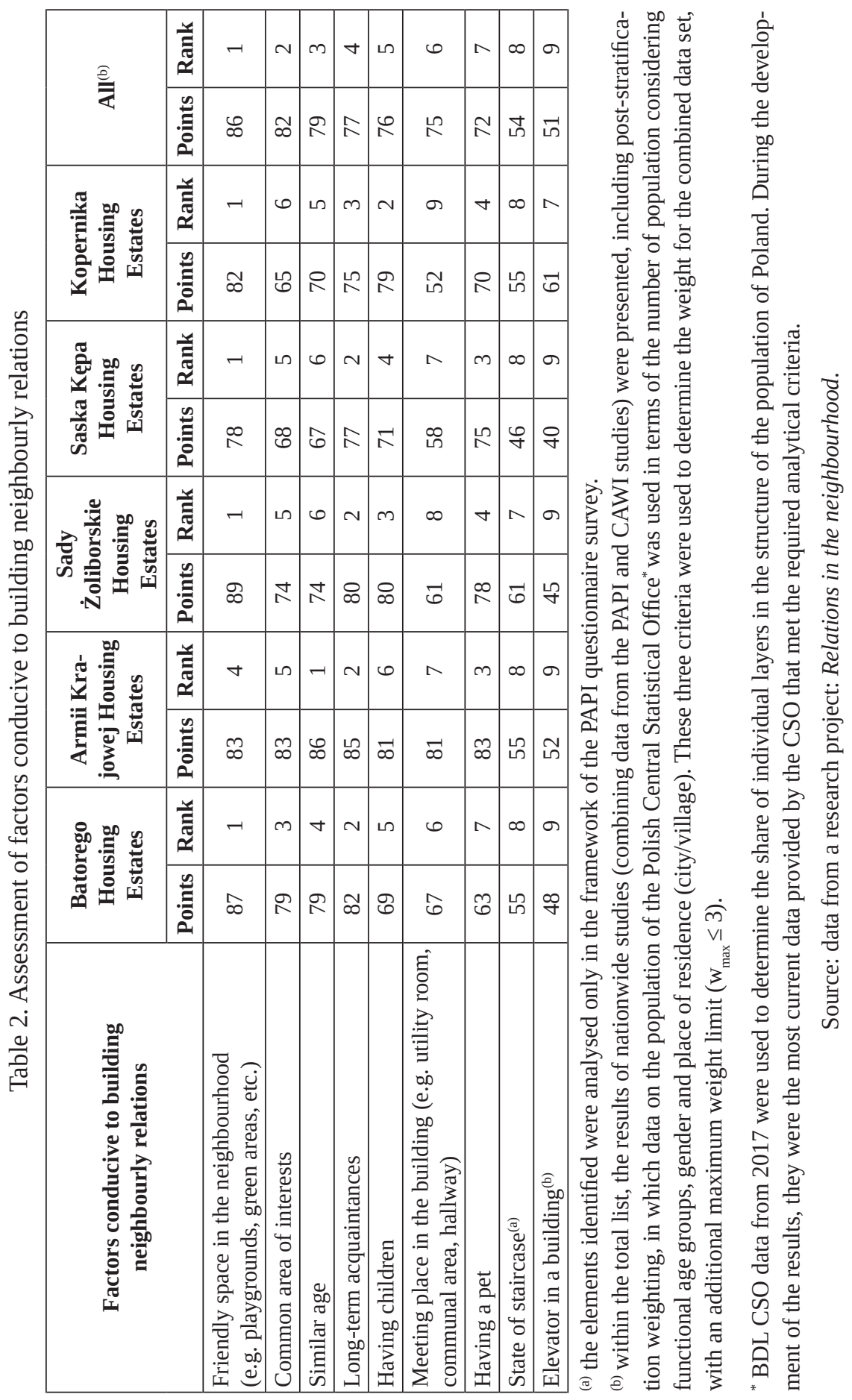


According to all the respondents, the key factor conducive to building neighbourly ties (80 points, 2nd in the ranking in general) was relatively less important to the surveyed residents of the housing estates, especially the residents of the Poznań Copernicus Housing Estate (65 points, 6th position) and the Saska Kępa Housing Estate (68 points, 5th position). Likewise, a similar age, according to the ranking, is relatively less important to the residents of the analysed housing estates (except for Armia Krajowa Housing Estate in Poznań). On the other hand, for residents of metropolitan housing estates, apart from a friendly space in the neighbourhood, long-term acquaintances are of paramount value (ranking in the estates $-2-3$, in the overall ranking - 4th place among the distinguished factors). Also, having children as a factor conducive to shaping neighbourly relations differentiates the inhabitants of the analysed housing estates. It was particularly important for the inhabitants of the Copernicus Housing Estates in Poznań (79 points, 2nd position) and Sady Żoliborskie Housing Estates (80 points, 3rd position), while the respondents from the Poznań Batory and Armii Krajowej Housing Estates (5th-6th position) attached no particular importance to it. The significance of the condition of the staircase or elevator in the building is assessed at a similarly low level (rankings oscillating around 7th-9th places).

\section{Summary and Discussion About Epistemic Consequences of Adopted Perspective}

Neighbourhood research has undergone a far-reaching transformation since the Chicago School research entered the scientific circuit about 100 years ago. There is nothing particularly surprising about that, especially since the change resulted more from the increasing interdisciplinary approach of urban studies than the evolution of urban sociology itself. The key factor here was the spatial turn, i.e. a tendency to build more profound conclusions which main element is the place in question and not the subjectivity of people living in a given area. From this point of view, the proposed project goes against the current trends and concentrates on the mechanisms of constructing a neighbourhood community. Nevertheless, the starting point of the analysis is to capture the factors conducive to building neighbourly relations, in which environmental factors play an important role.

As it turned out, the main factor influencing neighbourly relations in all the surveyed areas was the lack of space for meetings that postulates 
the existence of an alternative model of reasoning, in which the specificity of space plays a key role. Here, the peculiarity of late modernist urbanism, in the Central European tradition called social modernism, pushes neighbourly relations into the context of one staircase or immediate neighbourhood. Hence the importance of both spatial factors (meeting places) and socializing factors is indicated.

The second most important factor was, however, highly social in nature and related to firmly embedded social rooting in the residence emplacement, which means social premises for building long-term relationships and a common platform of lifestyle and interests where spatial anchoring plays a less significant role. Further down the list were elements of the lifestyle that favoured a personal contact, such as having children or pets. The observed regularities indicated the need for further analyses using mechanisms of constructing neighbourly relations and e.g. premises of social self-organization. Its scope is networked and clearly goes beyond the context of the place of residence and natural contact between neighbours. In the case of the reconstructed project, the premise for choosing conceptualization is a reference to the tradition of sociological neoclassicism in which studies initiated in Poland by Florian Znaniecki play an important role.

The consequence of the adopted perspective, which can also be called paradigmatic, is the decrease of two types of conditions that resonate relatively strongly in the literature: on the one hand, the external context and thus e.g. systemic interactions that neighbourhood relations are a part of (such as supply and demand of housing or public policies), on the other hand, interactions resulting strictly from the physical proximity of residents, where the physicality of the environment constructs relations, similarly to an elevator creating social contact of a specific nature. It is probably worth to consider two further motives that give grounds for generalizations; on the one hand, the context of the operating subject and its subjective motivations or a will oriented towards others (resulting from the analysis of the collected data), on the other hand, a specific return to the pragmatic values that modernism brings within itself, such as the acceptable quality of social infrastructure related to the environment of the place of residence or something that can be called the modernist genus loci and the minimalist adjustment of space to provide the needed results. Despite its advanced nature, the project in question is to be treated as an introduction to further studies, which we encourage our readers to engage in. 


\section{References}

Bierwiaczonek, K. (2018). Mikropolis w perspektywie badań nad tożsamością przestrzenną i sąsiedztwem. Miscellanea Anthropologica et Sociologica, 19(1), 269-286.

Birch, D., Brown, E., Coleman, R. et al. (1979). The Behavioral Foundations of Neighborhood Change. Washington: United States. Dept. of Housing and Urban Development. Office of Policy Development and Research.

Bujwicka, A. (2011). Typy wielkomiejskiego sąsiedztwa wyobrażone a praktykowane stosunki sąsiedzkie mieszkańców Łodzi. Acta Universitatis Lodziensis. Folia Sociologica, 36, 101-119.

Cichocki, R., Jabkowski, P. (2018). Jakość życia mieszkańców Poznania w świetle wyników badań z lat 2002-2013. Poznań: Wydawnictwo Naukowe Uniwersytetu im. Adama Mickiewicza w Poznaniu.

Dębicki, M., Doliński, W. (2013). Sympatia i “ciepła obojętność” jako kategorie analityczne stosunku zgorzelczan do mieszkańców Görlitz. Opuscula Sociologica, 2(4), 7-30.

Galster, G. (2001). On the nature of neighbourhood. Urban Studies, 38(12), 2111-2124.

Jasińska-Kania, A. (red.). (2001). Trudne sq̨iedztwa: z socjologii konfliktów narodowościowych. Warszawa: Wydawnictwo Naukowe Scholar.

Kadushin, Ch. (1976). Networks and Circles in the Production of Culture. American Behavioral Scientist, 19, 769-784.

Kotus, J. (2007). Natura wielkomiejskich sq̨siedztw. Analiza subsqsiedzkich i sq̨siedzkich terytorialnych podsystemów społecznych w Poznaniu. Poznań: Wydawnictwo Naukowe Uniwersytetu im. Adama Mickiewicza w Poznaniu.

Kryczka, P. (1981). Społeczność osiedla mieszkaniowego w wielkim mieście: ideologie i rzeczywistość. Warszawa: Państwowe Wydawnictwo Naukowe.

Majer, A. (2016). Miasto w osobistym wymiarze. Studia Miejskie, 21, 9-28.

Misiak, W. (1993). Jakość życia w osiedlach miejskich. Wrocław: Wydawnictwo Uniwersytetu Wrocławskiego.

Niezabitowski, M. (2011). Relacje społeczne ludzi starszych w środowisku zamieszkania aspekty teoretyczne i empiryczne. Acta Universitatis Lodziensis. Folia Sociologica, $38,13-31$.

Nóżka, M., Bukowski, A., Smagacz-Poziemska, M., Kurnicki, K. (2018). Parkowanie i troska. Teoria praktyki w badaniach nad osiedlami wielkomiejskimi. Przegląd Socjologiczny, 67(1), 139-164.

Nóżka, M., Martini, N. (2015). Metody mobilne i wizualne w praktyce badawczej. Zastosowanie fotospaceru w socjologicznych badaniach map mentalnych i zachowań terytorialnych ludzi. Przeglq̨ Socjologii Jakościowej, 11(4), 34-50.

Paprzyca, K. (2009). Wpływ efektów sąsiedztwa na jakość warunków zamieszkania na terenach miejskich - wybrane zagadnienia. Środowisko Mieszkaniowe, 7, 95-97.

Park, Y., Rogers, G.O. (2015). Neighborhood Planning Theory, Guidelines, and Research: Can Area, Population, and Boundary Guide Conceptual Framing? Journal of Planning Literature, 30(1), 18-36. 
Pluciński, P. (2019). Horyzont socjologii i nauk społecznych w badaniach nad codziennością PRL. In: M. Choma-Jusińska, M. Kruszyński, T. Osiński (eds), Życie codzienne w PRL (pp. 13-30). Lublin-Warszawa: Instytut Pamięci Narodowej.

Pobłocki, K. (2011). Prawo do miasta i ruralizacja świadomości w powojennej Polsce. In: M. Nowak, P. Pluciński (eds), O miejskiej sferze publicznej. Obywatelskość i konflikty o przestrzeń (pp. 129-146). Kraków: Ha!art.

Rychliński, S. (1976). Rozpad sąsiedztwa w mieście amerykańskim. In: S. Rychliński (ed.), Wybór pism (pp. 398-436). Warszawa: Państwowe Wydawnictwo Naukowe. [1st ed. Przeglq̨d Socjologiczny/Sociological Review, 3(1-2)/(1935)].

Słania, B. (2011). (A)społeczność lokalna? Przemiany więzi społecznych na przykładzie dzielnicy Ksawera w Będzinie. Górnoślq̨skie Studia Socjologiczne, 2, 90-101.

Smagacz-Poziemska, M. (2017). Badania nad społecznościami lokalnymi i sąsiedztwami w mieście - perspektywa socjologiczna. In: G. Schneider-Skalska, E. Kusińska (eds), Miejskie środowisko mieszkaniowe/Urban housing environment (pp. 139-155). Kraków: Politechnika Krakowska.

Sokołowicz, M.E. (2017). Udogodnienia miejskie - element publicznego wymiaru zasobów mieszkaniowych. Acta Universitatis Lodziensis. Folia Oeconomica, 332(6), 125-143.

Sosnowski, A., Walkowiak, J. (1983). Sąsiedztwo i jego odzwierciedlenie w świadomości mieszkańców wielkomiejskich osiedli. Studia Socjologiczne, 1, 223-244.

Szwaja, K. (1970). Przemiany rodzin robotniczych pochodzenia wiejskiego w wielkim mieście, typescript reproduced, Poznań: Archiwum Instytutu Socjologii Uniwersytetu im. Adama Mickiewicza w Poznaniu.

Temkin, K., Rohe, W. (1996). Neighbourhood change and urban policy. Journal of Planning Education and Research, 15(3), 159-170.

Turowski, J. (1973). Socjologiczne aspekty społeczności osiedlowej. Studia Socjologiczne, 3.

Unruh, D.R. (1980). The nature of social worlds. The Pacific Sociological Review, 23(3), 271-296.

Węcławowicz, G. (2016). Urban Development in Poland, from the Socialist City to the Post-Socialist and Neoliberal City, The study has been realised within the confines of the research entitled "Social Polarisation in the Hungarian and Eastern-Central European 'New Town' Regions: Impacts of Transition and Globalisation” (K 106169), http:// rcin.org.pl/Content/62816/WA51_81767_151633-r2016_Urban-Developmentin.pdf, accessed: summer 2019.

Zemło, M. (2016). Florian Znaniecki's sociology of common-sense knowledge: An overview of the problem. Zeszyty Naukowe KUL, 59, 4(236).

Ziółkowski, J. (1964). Osiedle jako system społeczny. Studia Socjologiczne, 2, 183-209.

Ziółkowski, J. (1965). Urbanizacja, miasto, osiedle. Studia socjologiczne, Warszawa: Państwowe Wydawnictwo Naukowe.

Znaniecki, F., Ziółkowski, J. (1928/1984). Czym jest dla ciebie miasto Poznań? Warszawa: Państwowe Wydawnictwo Naukowe. 